http://heanoti.com/index.php/hn

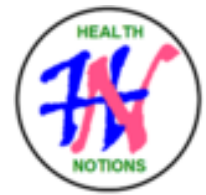

RESEARCH ARTICLE

URL of this article: http://heanoti.com/index.php/hn/article/view/hn20608

\title{
The Act of PMTCT Program to Decrease the Numbers of HIV in Situbondo Regency
}

\author{
Lea Ingne Reffita ${ }^{1(\mathrm{CA})}$, Byba Melda Suhita ${ }^{2}$ Indasah $^{3}$ \\ ${ }^{1(\mathrm{CA})}$ Postgraduate Program of STIKes Surya Mitra Husada Kediri, Indonesia; Lea_ingne@yahoo.com \\ (Corresponding Author) \\ ${ }^{2}$ Postgraduate Program of STIKes Surya Mitra Husada Kediri, Indonesia; bybamelda@yahoo.co.id \\ ${ }^{3}$ Postgraduate Program of STIKes Surya Mitra Husada Kediri, Indonesia
}

\begin{abstract}
PMTCT is an effort to prevent the occurrence of HIV infection in women and prevent HIV transmission from pregnant mother to baby. The number of women infected with Human Immunodeficiency Virus (HIV) from year to year has increased, along with the increasing number of men who have unprotected sexual intercourse, which will transmit HIV to their sexual partners. The purpose of this research is to explore the implementation of PMTCT program in Situbondo regency. The research design used was qualitative research with phenomenology approach. Data collection used indepth interview technique with semi-structured question. Sampling technique in this research used purposive sampling with the sample size of 8 informants from 17 informants. From the result of the research showed that the implementation process of PMTCT program influences the development of PMTCT program in every year and will cause positive impact for both health worker and pregnant woman. In the process of PMTCT program implementation was influenced by several factors, such as, there were factors that support from the implementation process of PMTCT program as well as heading off the factors. From these inhibiting factors, several strategies were used to support the PMTCT program. Based on the research, it is necessary to conduct further research on the implementation process of PMTCT program
\end{abstract}

Keywords: PMTCT (prevention of mother to child HIV transmission); Human Immunodeficiency Virus (HIV)

\section{INTRODUCTION}

\section{Background}

The number of women infected with Human Immunodeficiency Virus (HIV) from year to year has increased, along with the increasing number of men who have unprotected sexual intercourse, which will transmit HIV to their sexual partners. In pregnant women, HIV is not only a threat to the safety of the mother's soul, but also its affects of the unborn child because of the transmission that occurs from mother to baby. More than $90 \%$ of HIV-infected children, infected by mother-to-child transmission (MTCT) ${ }^{(1)}$.

Around the world in 2013 there are 35 million people living with HIV consisting of 16 million women and 3.2 million children < 15 years of age. The number of new HIV infections in 2013 is 2.1 million consisting of 1.9 million adults and 240,000 children $<15$ years of age ${ }^{(1)}$.

In Uganda the prevalence of HIV transmission from mother to infant without PMTCT is $1.53 \%$, but after service and coverage by PMTCT increased $80 \%$ (with $48 \%$ of nevirapine) can prevent some 13,000 infections during 2005-2010, decreasing HIV prevalence in neonatal to $1.19 \%$ through $2010^{(2)}$.

While in Indonesia the number of HIV patients from year to year also continues to increase. New HIV infections in 2016 was increasing up to 41,250 from 2015 at 30,935. While the cumulative number of new AIDS sufferers until 2016 is 86,780 people $^{(3)}$. While in East Java until 2016, the number of reported AIDS cases were 16,911 and new cases of HIV were 6,513 and 529 cases of HIV transmission from mother to baby ${ }^{(4)}$. While in the Situbondo District the number of HIV infection reaches 154 cases and 52 cases of AIDS in 2016. Meanwhile, based on preliminary study the number of HIV-positive pregnant women has increased up to 9 cases in 2016 and was increasing to 16 cases in 2017 until August.

\section{Purpose}

The purpose of this study is to explore the implementation of PMTCT (Prevention of Mother to Child HIV Transmission) program in Situbondo District. 
One of the things that is strongly suspected to be the cause of the high rate of HIV incidence, especially HIV that is transmitted from mother to child is the prevention of mother to child HIV transmission (PPIA) or Prevention Mother to Child Transmission (PMTCT) which has been implemented since 2004, especially in areas with a high rate of HIV epidemics, based on June 2012 data, showed that there are only 94 health-care facilities (85 Hospitals and 9 Local Clinic) that held PPIA services; as well as the service scope is low, aroud 28,314 pregnant women who were given HIV counseling and testing which 812 were positive, while pregnant women receiving ARVs were 685 people and the number of babies who received prophylactic ARVs were 752 people. $^{(3)}$

\section{METHODS}

This study used qualitative methods with phenomenology approach with a focus of research directed to determine the application of PMTCT programs in the working area of Situbondo District Health Office in depth. In addition, qualitative approach was expected to be disclosed the application of PMTCT program, supporting factors and strategies of PMTCT program in the working area of Situbondo District Health Office to reduce of HIV infection.

The location of this research was in Working Area of Health Office Situbondo Regency and conducted research in December 2017. Situbondo District Health Office has 17 districts spread in Situbondo. Sampling technique in this research used purposive sampling for sample determination with certain consideration. In this study the instruments used were the researchers themselves and interview guidelines in the form of questions that will be asked by researchers to respondents whose contents were questions about the application of PMTCT Program (Prevention Of Mother to Child HIV Transmission).

Researcher acts as instruments and data collection. Other supporting instruments used an instrument of questionnaire containing semi-structured questions. Other tools used were friends, field notes, mobile phones, and then documented in the form of transcript (note book field). Data analysis was semi-structured question which used inductive process that starts from collected data or special decisions and then taken general conclusion. Data processing was done by means of descriptive contents (contents analysis). Furthermore, it was reported and presented in descriptive description in relation to theory. The presence of the researcher explicitly illustrates the research report. Researcher's role as full participant. The presence of the researcher was known as a researcher by the subject or informant.

\section{RESULTS}

The results of this study get an overview related to the analysis of PMTCT (Prevention of Mother to Child HIV Transmission) program in Situbondo District. From this research got the themes include:

1. The process of implementing the PMTCT program

The PMTCT program implementation process was carried out by providing prevention of HIV transmission to women of reproductive age

2. Factors that affect the implementation of the PMTCT program

Factors affecting the implementation of the PMTCT program were the Integrated ANC region officers and programmers as well as the role of cross-sectoral role in the implementation of the PMTCT program.

3. Strategies to support the PMTCT program

The strategies used were counseling conducted in pregnant women's classes or at the time ANC was integrated and when pregnant women come to perform routine checks.

\section{DISCUSSION}

\section{The Process of Implementing the PMTCT Program}

Based on the results of the research, it was found that the implementation process of PMTCT program was done by giving the prevention of HIV transmission to women of reproductive age which was done by disseminating Communication, Information and Education (IEC) about HIV-AIDS and reproductive health both individual and group. This is done when the pregnant mother will perform ANC routine, before ANC pregnant mother first given counseling personally then given informed consent to be given service of HIV test, if mother willing to be given HIV service then the next action is HIV test but if pregnant women are cured then the midwives will not stop at that time but rather provide re-counseling for pregnant women are willing to be tested HIV.

At the United Nations General Assembly Special Session on HIV / AIDS (UNGASS) (2007) ${ }^{(5)}$ meeting committed to reduce $20 \%$ of infants infected with HIV / AIDS in 2005, and 50\% by 2010, and ensure $80 \%$ of pregnant women who visit Antenatal Care (ANC) services for counseling and HIV / AIDS prevention services. 
Interventions for the prevention of mother-to-child transmission of HIV with good intervention then the risk of mother-to-child HIV transmission of $25-45 \%$ can be reduced to less than $2 \%$. Based on the result of the research, all informants provide services to this PMTCT program by disseminating information about HIV / AIDS, giving counseling. Counseling can also be conducted in pregnant women's classes, where the danger of HIV virus spread and related issues about HIV as well as recommendations for testing HIV.

\section{Factors that Affect the Implementation of the PMTCT Program}

From the results of this study found that factors that support PMTCT programs include regional officers and ANC Integrated programmers there are also other factors namely the existence of cross-sectoral role in the implementation of PMTCT program.

Involving field staff in informing communities and access to health services, explaining ways of reducing the risk of HIV and STI transmission including the use of condoms and sterile syringes, involving all parties in the community (religious leaders, community leaders, peer support groups, HIV-cin aring community) in eliminating stigma and discrimination ${ }^{(3)}$.

This is in accordance with the results of research undertaken are factors that affect the implementation of PMTCT program is a regional officer and programmer ANC Integrated and the role of cross-sector in the implementation of PMTCT program.

\section{Strategies to Support the PMTCT Program}

The results of this study are informed that the strategies used to support the PMTCT program are to conduct counseling in pregnant women's classes or at the time of integrated ANC and when pregnant women come for routine examination.

Disseminate Communication, Information and Education (IEC) on HIV-AIDS and reproductive health both individuals and groups ${ }^{(2)}$ is a form of counseling that can be done to prevent HIV transmission.

There are informants who explain one of the strategies done is with the program. Where the "care taker" program is the contributing factor is the male health man "sakera" because it sees from the difficulties of the demographic conditions in the areas that do not support. Through this "sakera care" program, the puskesmas determines the point of pick-up where later the district officer who visits the home can give the patient's blood sample or the pregnant mother at the point of pick-up. The establishment of this "care taker" program is aimed at increasing the dedication of health workers in order to decrease MMR and IMR.

\section{CONCLUSION}

From the results of this study it can be seen that the process of PMTCT program implementation is done by giving the prevention of HIV transmission in women of reproductive age. Factors supporting the PMTCT program were found to support the PMTCT program, those are regional officers and ANC Integrated programmers, other factors, namely the role of cross-sectoral participation in the implementation of the PMTCT program. And there are specific strategies used to support the course of PMTCT programs, those are, counseling conducted in pregnant women's classes or at the time of integrated ANC and when pregnant women come to conduct routine checks.

From the results of this study is expected to improve the quality of services and competencies of special officers for HIV besides is considering to provide PMTCT services not only in pregnant women but will be given to all women of reproductive age.

\section{REFERENCES}

1. Dinkes Prov. Jatim. Health Profile of East Java Province in 2016 (Profil Kesehatan Provinsi Jawa Timur Tahun 2016).. Surabaya: Dinkes Prov. Jatim; 2016.

2. Dirjen P2\&PL. Training Module for Managers of Disease Control Programs in Indonesia (Modul Pelatihan Bagi Pengelola Program Pengendalian Penyakit di Indonesia). Jakarta: Dirjen P2\&PL Kemenkes RI; 2007.

3. Kemenkes RI.. INFODATIN: Indonesian Ministry of Health Data and Information Center (INFODATIN: Pusat Data dan Informasi Kementerian Kesehatan RI). Jakarta: Kemenkes RI; 2013.

4. Hartati N, Suratiah, Mayuni IGAO. Pregnant women and HIV-AIDS (Ibu Hamil dan HIV-AIDS). Gempar: Jurnal Ilmiah Keperawatan. 2009:39-44.

5. UNAIDS. UNAIDS report on the global AIDS epidemic [Internet]. 2010. [cited 2017 Aug 01]. Available from: http://www.avert.org/worldstats.htm 